\title{
Nitrifying and heterotrophic population dynamics in biofilm reactors: effects of hydraulic retention time and the presence of organic carbon
}

\author{
Regina Nogueira ${ }^{\mathrm{a}, \mathrm{b}}$, Luís F. Melo ${ }^{\mathrm{a}}$, Ulrike Purkhold ${ }^{\mathrm{b}}$, Stefan Wuertz ${ }^{\mathrm{c}}$, \\ Michael Wagner ${ }^{\mathrm{b}, *}$ \\ ${ }^{a}$ Department of Chemical Engineering, Faculty of Engineering of Porto, LEPAE, Porto, Portugal \\ ${ }^{\mathrm{b}}$ Lehrstuhl fur Mikrobiologie, Technische Universität München, Am Hochanger 4, D-85350 Freising, Germany \\ ${ }^{\mathrm{c}}$ Technische Universität München, Am Coulombwall, D-85748 Garching, Germany
}

Received 29 September 2000; received in revised form 09 January 2001; accepted 1 February 2001

\begin{abstract}
Two biofilm reactors operated with hydraulic retention times of 0.8 and $5.0 \mathrm{~h}$ were used to study the links between population dynamics and reactor operation performance during a shift in process operation from pure nitrification to combined nitrification and organic carbon removal. The ammonium and the organic carbon loads were identical for both reactors. The composition and dynamics of the microbial consortia were quantified by fluorescence in situ hybridization (FISH) with rRNA-targeted oligonucleotide probes combined with confocal laser scanning microscopy, and digital image analysis. In contrast to past research, after addition of acetate as organic carbon nitrification performance decreased more drastically in the reactor with longer hydraulic retention time. FISH analysis showed that this effect was caused by the unexpected formation of a heterotrophic microorganism layer on top of the nitrifying biofilm that limited nitrifiers oxygen supply. Our results demonstrate that extension of the hydraulic retention time might be insufficient to improve combined nitrification and organic carbon removal in biofilm reactors. (C) 2002 Elsevier Science Ltd. All rights reserved.
\end{abstract}

Keywords: Nitrification; Biofilm; Organic carbon; Hydraulic retention time; Fluorescence in situ hybridization

\section{Introduction}

The competition between heterotrophic and nitrifying bacteria for substrates (oxygen and ammonia) and space in biofilms is of major practical importance and thus has been the subject of several previous studies (for example [1-3]). According to these investigations, competition in biofilms results in a stratified biofilm structure, the fast growing heterotrophic bacteria being placed in the outer layers, where both substrate concentration and detach-

*Corresponding author. Tel.: +49-8161-71-5444; fax: +498161-71-5475.

E-mail address: wagner@mikro.biologie.tu-muenchen.de (M. Wagner). ment rate are high, while the slow growing nitrifying bacteria stay deeper inside the biofilm. Thus a heterotrophic layer can form above the nitrifiers in the biofilm, which constitutes a disadvantage to them when the bulk liquid oxygen concentration is low. In this case oxygen limitation resulting from consumption and resistance to mass transfer within the heterotrophic layer affects the nitrification performance negatively. As long as the bulk oxygen concentration is high enough to preclude its depletion in the biofilm, however, the heterotrophic layer can also have a positive effect on the nitrifiers by protecting them from detachment [4].

One possible approach to minimize the competition of heterotrophs and nitrifiers for oxygen is their spatial separation into a nitrifying biofilm population and a 
heterotrophic population in suspension. This separation can be achieved by extending the reactor's hydraulic retention time. At comparatively long hydraulic retention times, the fast growing heterotrophic microorganisms (with reciprocal maximum specific growth rates smaller than the selected hydraulic retention time) grow mainly in suspension while the slow growing nitrifiers form biofilms [2]. However, in this study the reactor was operated at a high oxygen concentration of $6 \mathrm{mgl}^{-1}$, a condition which did also allow full nitrification in a conventional biofilm reactor (nitrifiers and heterotrophs in the biofilm) [2].

Reactors with a spatial separation of heterotrophic and nitrifying activity for the treatment of effluents with a high chemical oxygen demand (COD)/ $\mathrm{NH}_{4}^{+}-\mathrm{N}$ ratio can be very attractive for future practical applications if (i) it can be demonstrated that these reactors allow complete nitrification at a relatively low dissolved oxygen concentration and if (ii) the energy savings in aeration relatively to the traditional process compensate the investment costs in the construction of a bigger reactor required due to its longer retention time. So far the effects of influent composition and operational conditions were studied with respect either to total reactor performance (macroscale studies) or to biofilm composition and structure (microscale studies), but hardly to both simultaneously (for example [3]).

The research subjects of this study were the effects of different hydraulic retention times and changes in the organic carbon dosing on the population dynamics of nitrifying biofilm reactors operated at around $2 \mathrm{mgl}^{-1}$ dissolved oxygen. The specific objectives were: (i) to identify and quantify nitrifying and heterotrophic bacteria in the biofilm and in suspension using a set of rRNAtargeted oligonucleotide probes for fluorescence in situ hybridization (FISH), (ii) to correlate changes in microbial community composition in the biofilm and suspension with reactor performance during a shift from pure nitrification to combined nitrification and organic carbon removal, and (iii) to asses the recovery of the nitrification process after a shift back to pure nitrification.

\section{Materials and methods}

\subsection{Biofilm reactors}

Two laboratory-scale circulating bed reactors (CBR) of 1.21 each [5] were employed for this study. This type of airlift reactor has a rectangular geometry of $310 \mathrm{~mm}$ height and $60 \mathrm{~mm} \times 60 \mathrm{~mm}$ cross-section and is separated in an up-flow aerated section and a down-flow non-aerated one by a vertical wall (Fig. 1). High density polyethylene granulate with a particle size of $1 \mathrm{~mm}$ and a density of $731 \mathrm{~kg} \mathrm{~m}^{-3}$ was used as support material for biofilm growth. The superficial air velocity in both

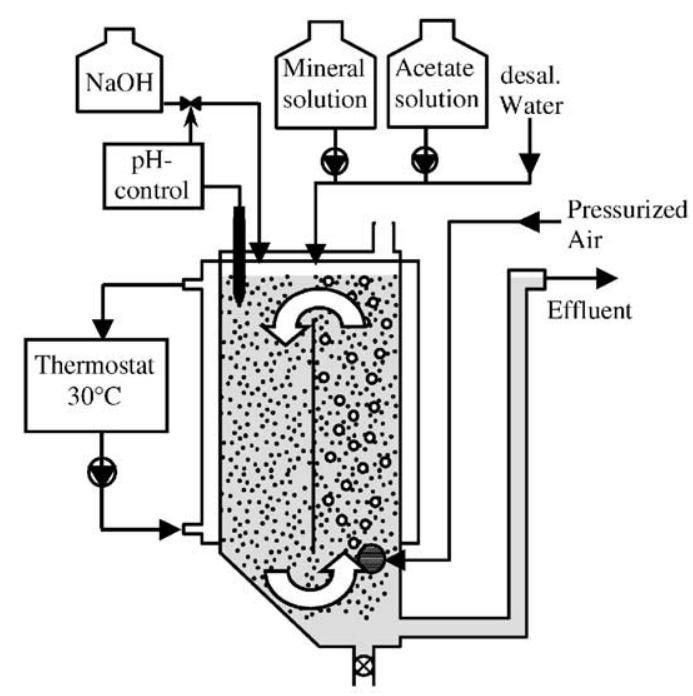

Fig. 1. Schematic diagram of continuous circulating bed reactor set-up.

reactors (defined as the air flow rate divided by the aerated reactor cross-section) was set at $0.003 \mathrm{~m} \mathrm{~s}^{-1}$. The temperature was maintained at $30^{\circ} \mathrm{C}$, and the $\mathrm{pH}$ was kept at 7.5 by adding sodium hydroxide $(1 \mathrm{M})$. The experimental protocol included 4 phases (Fig. 2). The corresponding experimental conditions are summarized in Table 1 .

Phase I. A CBR (hereafter reactor $\mathrm{R}_{0}$ ) was filled with nitrifying biofilm particles (23 volume percent) obtained from a nitrifying circulating bed reactor, which was maintained at identical operating conditions. The biofilm particles had been stored at $4{ }^{\circ} \mathrm{C}$ for 90 days prior to inoculation of reactor $\mathrm{R}_{0}$. An ammonium solution was supplied continuously ( $\mathrm{N}$ operation mode), with a retention time of $0.70 \mathrm{~h}$. During phase I a stable nitrifying biofilm was established.

Phase II. Half of the biofilm particles from reactor $\mathrm{R}_{0}$ were transferred to a second identical reactor. Both CBRs (hereafter reactors $R_{1}$ and $R_{2}$ ) were operated simultaneously with retention times of $0.8 \mathrm{~h}$ for reactor $\mathrm{R}_{1}$ and $5.0 \mathrm{~h}$ for reactor $\mathrm{R}_{2}$. The ammonium load supplied to each reactor was approximately half of the value used in phase $\mathrm{I}$ in order to maintain a constant $\mathrm{NH}_{4}^{+}-\mathrm{N}$ load to biomass ratio $\left(0.46 \mathrm{~kg} \mathrm{~kg}^{-1} \mathrm{~d}^{-1}\right)$, and still no organic carbon was added ( $\mathrm{N}$ operation mode).

Phase III. Acetate as an organic carbon source was supplied to reactors $\mathrm{R}_{1}$ and $\mathrm{R}_{2}$ at the same $\mathrm{COD} / \mathrm{NH}_{4}^{+}$$\mathrm{N}$ mass ratio $(\mathrm{C}+\mathrm{N}$ operation mode) in order to investigate the effect of organic carbon on the nitrification performance of reactors operating at different retention times.

Phase IV. Discontinuation of the supply of acetate to reactors $R_{1}$ and $R_{2}$ in order to study the recovery of the nitrification process ( $\mathrm{N}$ operation mode). 


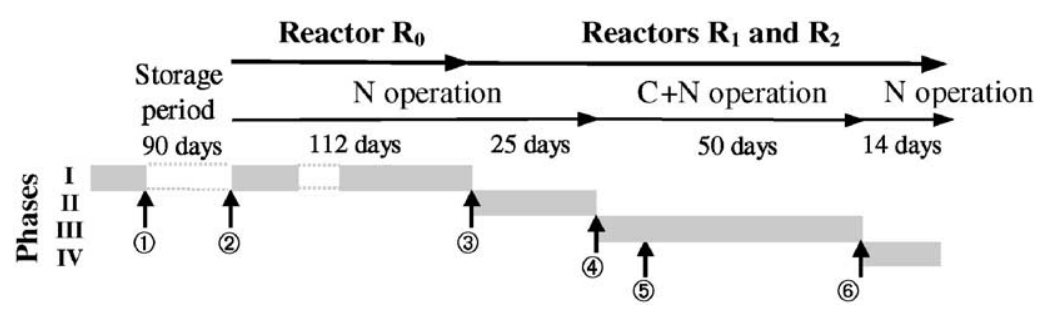

Fig. 2. Schematic diagram describing the experimental phases. The arrows indicate biofilm and suspended biomass sampling times.

Table 1

Operating conditions and performance of reactors $\mathrm{R}_{0}, \mathrm{R}_{1}$, and $\mathrm{R}_{2}$. For all parameters average values are given for the different phases of operation

\begin{tabular}{|c|c|c|c|c|c|c|c|c|c|c|}
\hline \multicolumn{2}{|c|}{$\begin{array}{l}\text { Phase/ } \\
\text { mode of } \\
\text { operation }\end{array}$} & \multicolumn{2}{|l|}{ Influent } & \multicolumn{2}{|c|}{$\mathrm{NH}_{4}^{+}-\mathrm{N}$ load } & \multirow[t]{2}{*}{$\begin{array}{l}\mathrm{NH}_{4}^{+}-\mathrm{N} \\
\text { removal } \\
(\%)\end{array}$} & \multicolumn{2}{|c|}{ COD load } & \multirow[t]{2}{*}{$\begin{array}{l}\text { COD } \\
\text { removal } \\
(\%)\end{array}$} & \multirow[t]{2}{*}{$\begin{array}{l}\mathrm{COD} / \mathrm{N} \\
\text { applied } \\
\left(\mathrm{g} \mathrm{g}^{-1}\right)\end{array}$} \\
\hline & & $\mathrm{NH}_{4}^{+}-\mathrm{N}$ & $\operatorname{COD}\left(\mathrm{kg} \mathrm{m}^{-3}\right)$ & Applied & $\begin{array}{l}\text { Removed } \\
\left(\mathrm{kg} \mathrm{m}^{-3} \mathrm{~d}^{-1}\right)\end{array}$ & & Applied & $\begin{array}{l}\text { Removed } \\
\left(\mathrm{kg} \mathrm{m}^{-3} \mathrm{~d}^{-1}\right)\end{array}$ & & \\
\hline \multicolumn{11}{|c|}{ Reactor $\mathrm{R}_{0}$ hydraulic retention time of $0.7 \mathrm{~h}$} \\
\hline I & $\mathrm{N}$ & 0.037 & $-^{\mathrm{a}}$ & 1.26 & 1.20 & 95 & - & - & - & - \\
\hline \multicolumn{11}{|c|}{ Reactor $\mathrm{R}_{1}$ hydraulic retention time of $0.8 \mathrm{~h}$} \\
\hline II & $\mathrm{N}$ & 0.020 & 0.01 & 0.61 & 0.60 & 98 & 0.33 & 0.04 & 12 & 0.53 \\
\hline III & $\mathrm{C}+\mathrm{N}$ & 0.022 & 0.03 & 0.65 & 0.45 & 69 & 0.85 & 0.61 & 72 & 1.30 \\
\hline IV & $\mathrm{N}$ & 0.019 & 0.01 & 0.57 & 0.51 & 90 & 0.17 & 0.05 & 29 & 0.30 \\
\hline \multicolumn{11}{|c|}{ Reactor $\mathrm{R}_{2}$ hydraulic retention time of $5.0 \mathrm{~h}$} \\
\hline II & $\mathrm{N}$ & 0.100 & 0.02 & 0.48 & 0.48 & 100 & 0.10 & 0.04 & 40 & 0.21 \\
\hline III & $\mathrm{C}+\mathrm{N}$ & 0.109 & 0.14 & 0.53 & $0.53 \rightarrow 0$ & $100 \rightarrow 0$ & 0.68 & 0.61 & 90 & 1.28 \\
\hline IV & $\mathrm{N}$ & 0.117 & 0.02 & 0.56 & 0.53 & 94 & 0.08 & 0.05 & 63 & 0.14 \\
\hline
\end{tabular}

Phases I, II and IV are characteristic of a pure nitrification process, while phase III corresponds to a combined nitrification and organic carbon removal process.

\subsection{Media}

During the experimental phases I, II and IV (N operation mode) $3.4 \mathrm{ml} \mathrm{min}^{-1}$ of an ammonium medium was delivered to each reactor. The medium contained $\left(\mathrm{NH}_{4}\right)_{2} \mathrm{SO}_{4}\left(0.59 \mathrm{~g} \mathrm{l}^{-1}\right), \mathrm{NaHCO}_{3}\left(0.19 \mathrm{~g} \mathrm{l}^{-1}\right), \mathrm{KH}_{2} \mathrm{PO}_{4}$ $\left(0.06 \mathrm{~g} \mathrm{l}^{-1}\right), \mathrm{CaCl}_{2} 2 \mathrm{H}_{2} \mathrm{O}\left(0.014 \mathrm{~g} \mathrm{l}^{-1}\right)$ and trace elements.

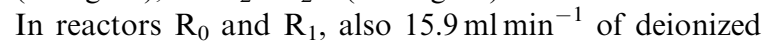
water was added to the reactors to obtain the desired hydraulic retention time. During phase III $(\mathrm{C}+\mathrm{N}$ operation mode) $1.7 \mathrm{ml} \mathrm{min}^{-1}$ of a sterilized acetate solution $\left(\mathrm{CH}_{3} \mathrm{COONa} 3 \mathrm{H}_{2} \mathrm{O}, 0.71 \mathrm{gl}^{-1}\right)$ was added separately to reactors $\mathrm{R}_{1}$ and $\mathrm{R}_{2}$. In order to maintain the retention time in both reactors constant, the ammonium medium's volumetric flow rate was reduced to half, and its concentration was doubled.

\subsection{Overall kinetics}

The macroscale reactor performance was evaluated from effluent samples filtered with $0.22 \mu \mathrm{m}$ membrane filters. COD, ammonia plus ammonium, nitrite and nitrate were determined photometrically (LCK, Dr. Lange). Biofilm and suspended biomass total solids were measured according to APHA [6] using $0.22 \mu \mathrm{m}$ membrane filters. Prior to this analysis, the biofilm was detached from the support material by an ultrasonic homogenizer (Bandelin electronics D-1000, Berlin) treatment $(120 \mathrm{~s}$ at $50 \mathrm{~W})$. The dissolved oxygen concentration was measured with an oxygen electrode (WTW, model Oxi 340-A).

\subsection{Fluorescence in situ hybridization, microscopy and quantification of probe-targeted bacteria}

Microbial population dynamics in biofilm particles and suspended biomass was evaluated using FISH with rRNA-targeted oligonucleotide probes. Samples 1-6 


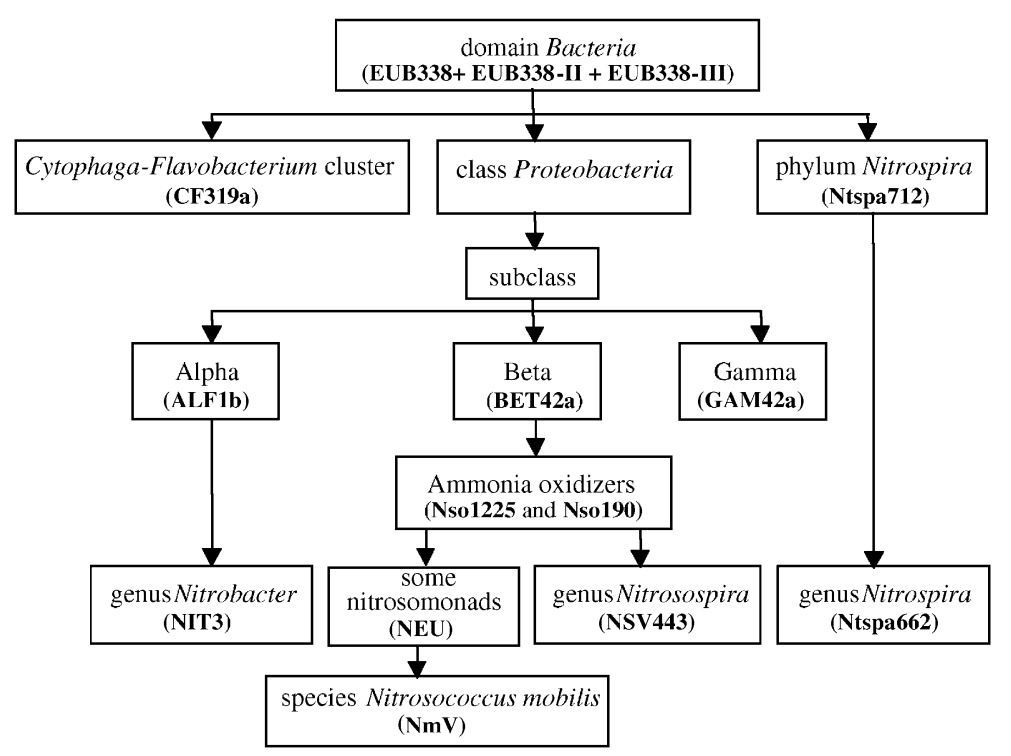

Fig. 3. Specificity of the rRNA-targeted oligonucleotide probes used for in situ identification of nitrifiers and heterotrophic bacteria.

(Fig. 2) were taken from the reactors and immediately fixed with paraformaldehyde. During phases I and II (N operation) only biofilm was sampled since the suspended biomass concentration was very low, while during phase III (acetate addition) both biofilm and suspended biomass samples were taken.

In situ characterization of microbial populations followed a top to bottom approach (Fig. 3). First the samples were hybridized with a probe set (EUB338, EUB338-II, EUB338-III) designed to target almost all bacteria [7], then with previously published group specific probes (Fig. 3; [8,9]). The ammonia-oxidizing and nitrite-oxidizing bacteria were identified using previously published probes (Fig. 3; [10-14]).

Oligonucleotide probes were purchased as derivatives labeled with the fluorescent dyes Cy3, Cy5, and 5(6)carboxyfluorescein-N-hydroxysuccinimide-ester

(FLUOS), respectively (Interactiva, Ulm, Germany). FISH was performed using the hybridization and washing buffers as described by Manz et al. [8]. A Zeiss LSM 510 laser scanning confocal microscope (Zeiss, Jena, Germany) was used for image acquisition. For quantification of probe-targeted bacteria, simultaneous hybridizations were performed with $\mathrm{Cy} 3$ labeled specific probes and the FLUOS labeled bacterial probe set. The relative biovolume defined as the ratio between the area of probe-targeted bacteria to the area of all bacteria detectable by FISH was determined for each probe in 20 randomly recorded confocal images (thickness $1 \mu \mathrm{m}$ ) using the procedure described by Schmid et al. [15]. Biofilm thickness was determined for fresh, unfixed biofilm samples which were stained with a $0.25 \mathrm{gl}^{-1}$ fluorescein isothiocianate solution for $3 \mathrm{~h}$ at room temperature, using CLSM optical sectioning in the sagittal $(x z)$ direction.

\subsection{Comparative sequence analyses of the amo $A$ gene}

High resolution analyses of ammonia-oxidizer diversity in reactor $\mathrm{R}_{0}$ was performed using the gene encoding the catalytic subunit of the ammonia-monooxygenase enzyme (amo $A$ ) as a marker. Amplification, cloning, sequencing and phylogenetic analyses of the biofilm-derived amo $A$ fragments was performed as described by Purkhold et al. [16].

\section{Results}

\subsection{Reactor performance}

\subsubsection{Phase I}

One of the main drawbacks of biological nitrification processes is the requirement of a long start-up period. By using biofilm particles as inoculum, the start-up period of reactor $R_{0}$ in phase I could be reduced to 4 days after which the ammonium removal efficiency had reached $95 \%$. Subsequently, $\mathrm{R}_{0}$ 's biofilm particles were split between reactors $R_{1}$ and $R_{2}$ to ensure that both reactors had the same original microbial population composition. 


\subsubsection{Phases II to IV}

Fig. 4 (A-D) depicts the performance of reactors $R_{1}$ and $R_{2}$ operated with retention times of 0.8 and $5.0 \mathrm{~h}$, respectively, during pure nitrification (phases II and IV) and combined nitrification and organic carbon removal (phase III). Tables 1 and 2 summarize the experimental results obtained during reactors operation and the characterization of biofilm and suspended biomass. Though acetate as organic carbon source was only added during phase III, there was a certain background COD in the influent during phases I, II and IV (Table 1; Figs. 4B and D) deriving from oxidizable matter in the deionized water source. However, during these phases maximal $63 \%$ of the incoming COD was removed demonstrating that a significant fraction of these compounds were not degraded in the reactors.
During phase II, both reactors had a stable performance, no nitrite accumulation was observed and the $\mathrm{NH}_{4}^{+}-\mathrm{N}$ effluent concentration was below $1.0 \mathrm{mgl}^{-1}$ corresponding to an ammonium removal efficiency higher than $95 \%$. The biofilm characterization at the end of phase II showed similar biofilm thickness (41 and $42 \mu \mathrm{m})$, and biofilm mass concentration (2.48 and $2.43 \mathrm{~kg} \mathrm{~m}^{-3}$ ) in reactors $\mathrm{R}_{1}$ and $\mathrm{R}_{2}$.

Shortly after the addition of acetate to reactor $R_{1}$ (start of phase III), the ammonium removal rate decreased from 0.65 to $0.45 \mathrm{~kg} \mathrm{~m}^{-3} \mathrm{~d}^{-1} \quad(69 \%)$ and hereafter, was constant (Fig. 4A). Due to a mechanical problem in the ammonium dosing pump, reactor $R_{1}$ received an ammonium overload 10 days after the start of phase III (gray area in Fig. 4A). The ammonium removal rate, however, remained constant. In reactor $R_{2}$

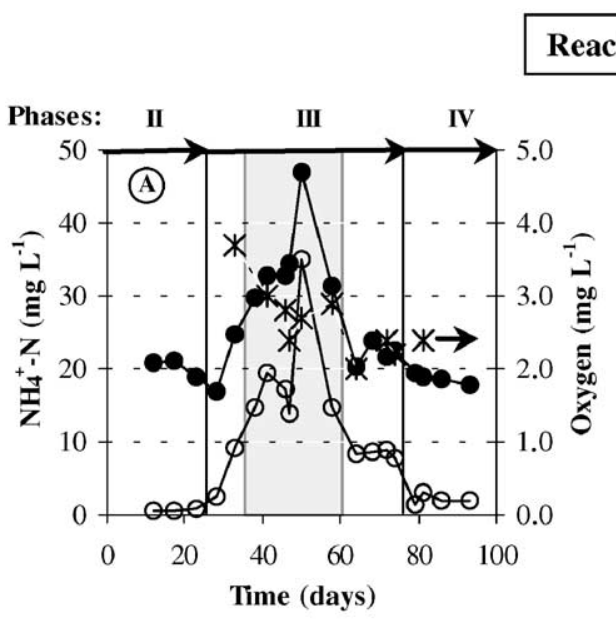

Reactor $\mathbf{R}_{1}$
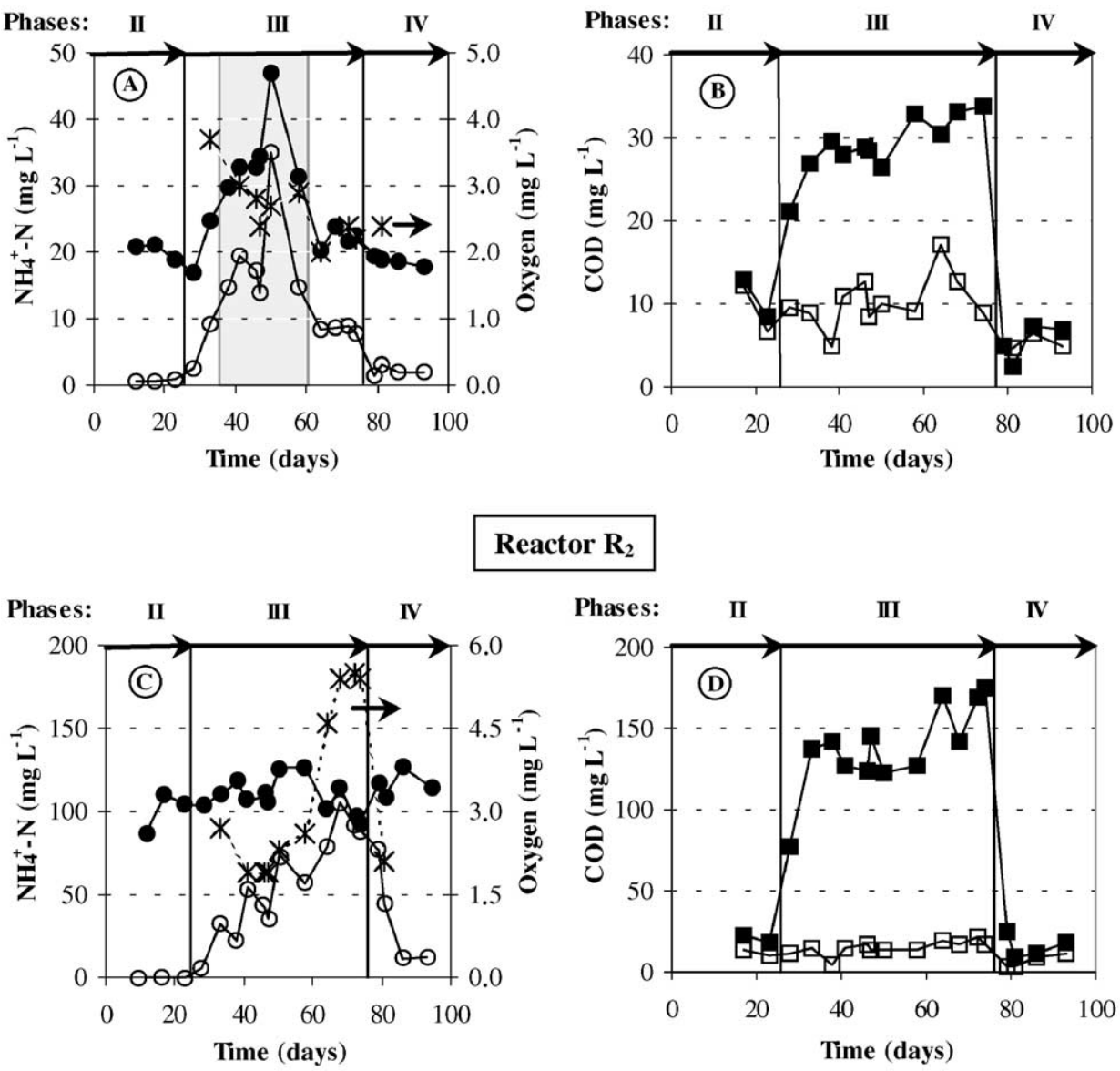

Reactor $\mathbf{R}_{2}$

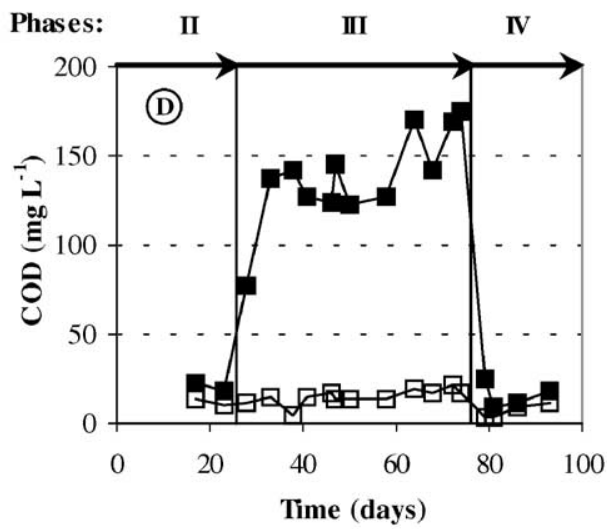

Fig. 4. Time changes of $\mathrm{NH}_{4}^{+}-\mathrm{N}, \mathrm{COD}$ and oxygen during operation of reactors $\mathrm{R}_{1}$ and $\mathrm{R}_{2}$ with pure nitrification (phases II and IV) and combined nitrification and organic carbon removal (phase III). Closed symbols correspond to influent concentrations and open symbols to effluent concentrations. *Corresponds to oxygen concentrations. 
Table 2

Characterization of biofilm and suspended biomass in reactors $\mathrm{R}_{0}, \mathrm{R}_{1}$, and $\mathrm{R}_{2}$ during the different phases of operation. Values listed in the table are the average $\pm 95 \%$ confidence interval

\begin{tabular}{|c|c|c|c|c|}
\hline $\begin{array}{l}\text { Mode } \\
\text { sample }\end{array}$ & & $\begin{array}{l}\text { Biofilm mass per } \\
\text { reactor volume }\left(\mathrm{kg} \mathrm{m}^{-3}\right)\end{array}$ & $\begin{array}{l}\text { Suspended solids } \\
\text { concentration }\left(\mathrm{kg} \mathrm{m}^{-3}\right)\end{array}$ & $\begin{array}{l}\text { Biofilm thickness } \\
(\mu \mathrm{m})\end{array}$ \\
\hline \multicolumn{5}{|c|}{ Reactor $\mathrm{R}_{0}$ hydraulic retention time of $0.7 \mathrm{~h}$} \\
\hline $\mathrm{N}$ & 3 & $2.70 \pm 0.80$ & $-^{\mathrm{a}}$ & $33 \pm 5$ \\
\hline \multicolumn{5}{|c|}{ Reactor $\mathrm{R}_{1}$ hydraulic retention time of $0.8 \mathrm{~h}$} \\
\hline $\mathrm{N}$ & 4 & $2.48 \pm 0.37$ & - & $41 \pm 2$ \\
\hline $\mathrm{C}+\mathrm{N}$ & 5 & $2.49 \pm 0.37$ & - & - \\
\hline $\mathrm{C}+\mathrm{N}$ & 6 & $2.54 \pm 0.41$ & $0.46 \pm 0.01$ & $44 \pm 3$ \\
\hline \multicolumn{5}{|c|}{ Reactor $\mathrm{R}_{2}$ Hydraulic retention time of $5.0 \mathrm{~h}$} \\
\hline $\mathrm{N}$ & 4 & $2.43 \pm 0.40$ & - & $42 \pm 3$ \\
\hline $\mathrm{C}+\mathrm{N}$ & 5 & $2.72 \pm 0.40$ & - & - \\
\hline $\mathrm{C}+\mathrm{N}$ & 6 & $3.63 \pm 0.38$ & $0.61 \pm 0.04$ & $56 \pm 5$ \\
\hline
\end{tabular}

a

the ammonium removal continuously decreased to zero within 50 days (Fig. 4C), while the dissolved oxygen concentration simultaneously increased (Fig. 4B). A constant COD removal rate of $0.61 \mathrm{~kg} \mathrm{~m}^{-3} \mathrm{~d}^{-1}$ was reached within 5 days in both reactors (Figs. 4B and D) and no nitrite accumulation was observed during the entire phase III. The increase of biofilm thickness and mass after carbon addition was more pronounced in reactor $R_{2}$ than in $R_{1}$ (Table 2).

The amount of biomass found in the reactors during phase III was by a factor of 10 to 40 higher than the value expected for theoretical equilibrium between bacteria growth rate and dilution rate (Table 2). This inconsistency was obviously caused by an accumulation of mostly heterotrophic biomass in the reactors' bottom and effluent tubes increasing the actual sludge retention time considerably. In reactor $R_{2}$ this effect was supported by the lower hydraulic retention time, leading to a higher biomass accumulation than in $R_{1}$. The accumulated biomass was removed once per week and included in the samples for suspended solids quantifications and FISH analyses of suspended cells.

After the discontinuation of acetate addition (phase IV) the ammonium removal in both reactors recovered and after a period of 14 days approx. $90 \%$ of the influent ammonium load was nitrified. In reactor $R_{2}$ the dissolved oxygen concentration decreased back to the value at the beginning of phase III.

\subsection{Diversity of nitrifying bacteria in the reactors}

The ammonia-oxidizing cells in all biofilm samples could be labeled simultaneously with probes BET42a, Nso1225 and Nso190. No ammonia-oxidizers belonging to the Nitrosospira-cluster were detected. A fraction of the ammonia-oxidizing population was detectable with probe NEU, while Nitrosococcus mobilis was absent. The NEU-positive subpopulation of ammonia-oxidizers is most likely affiliated with the Nitrosomonas europaea/ eutropha group [17]. Comparative sequence analyses of amo $A$ clones derived from the biofilm of reactor $\mathrm{R}_{0}$ independently confirmed the presence of two different groups of ammonia-oxidizers (Fig. 5). One amoA sequence cluster is closely related to Nitrosomonas europaea, most likely representing the NEU-positive ammonia-oxidizers, while the other amoA cluster is not closely related with any described ammonia-oxidizer reference strain. In both reactors the nitrite-oxidizing cells in the biofilm were affiliated with the genus Nitrospira during all phases of operation. Members of the genus Nitrobacter were only detected in the biofilm from reactor $\mathrm{R}_{2}(5.0 \mathrm{~h}$ retention time) during operation with acetate addition (Table 3 ).

\subsection{Diversity of heterotrophic bacteria in the reactors}

The heterotrophic bacteria present in the biofilm of reactor $\mathrm{R}_{2}$ were Proteobacteria of the alpha- and betasubclasses while in reactor $R_{1}$ only beta-subclass Proteobacteria could be detected (Table 3). In both reactors the microbial populations in the suspended biomass during phase III were Proteobacteria of the alpha-, beta- and gamma-subclasses and bacteria belonging to Cytophaga-Flavobacterium-cluster (Table 4).

The dominating microbial populations both in biofilm and suspended biomass during combined organic carbon and ammonia oxidation belong to the betasubclass of Proteobacteria. Concerning the two reactor 


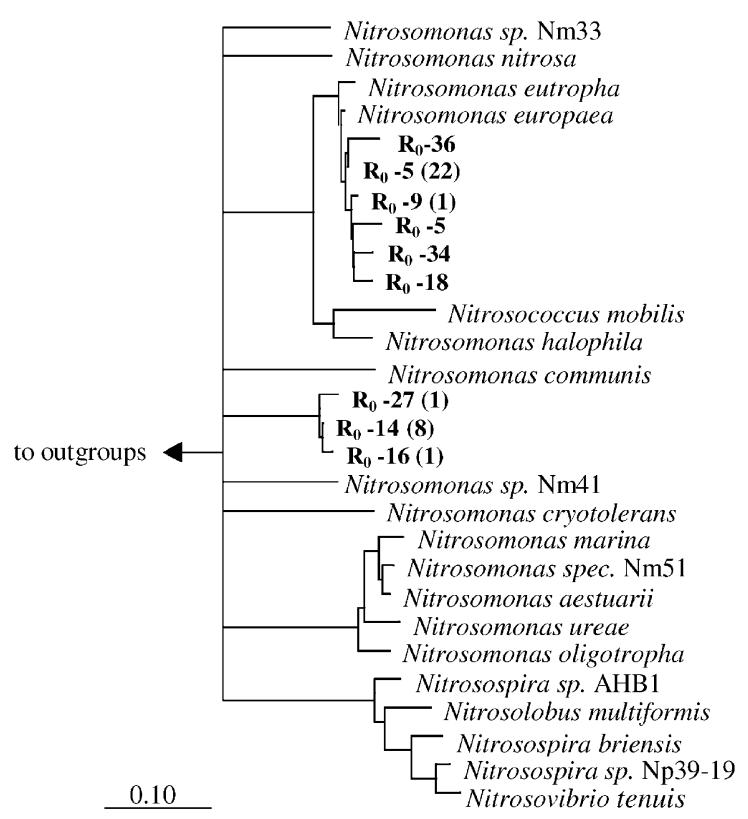

Fig. 5. Phylogenetic FITCH tree reflecting the relationships of the ammonia-oxidizers in reactor $\mathrm{R}_{0}$ based on amo $A$ sequences. The scale bar indicates the number of expected amino acid substitutions per site per unit of branch length. Numbers in brackets indicate the number of clones with almost identical sequences ( $>99 \%$ amino acid sequence similarity) which were retrieved from the reactor.

operation modes $(\mathrm{N}$ and $\mathrm{C}+\mathrm{N}$ operation) the major difference is that during pure nitrification all betasubclass Proteobacteria were ammonia-oxidizers, while during acetate dosing an additional presumably heterotrophic beta-subclass population developed. With respect to the different hydraulic retention times the major difference is a presumably heterotrophic alpha-subclass Proteobacteria population that occurred during pure nitrification only in reactor $\mathrm{R}_{2}$ biofilm and disappeared after introduction of acetate.

\subsection{Population dynamics in biofilm and suspended biomass}

Values for each probe's targeted-bacteria are depicted in Table 3 for biofilm and in Table 4 for suspended biomass. The relative biovolumes of the different microbial populations (determined by FISH) were normalized by taking into account the differences in biomass (measured as dry weight) in the different reactors and samples. The FISH biovolume percentages for the sample with the highest biomass per reactor volume (sample 6) were kept unchanged and the FISH percentages of the other samples were reduced according to the biomass differences.

The fraction of the heterotrophic beta-Proteobacteria population (HET) present in the biofilm of reactors $R_{1}$ and $\mathrm{R}_{2}$ can be determined as follows:

$\left(\text { Area }_{\text {BET 42a }}\right)_{\text {HET }}=$ Area $_{\text {BET } 42 a}-$ Area $_{\text {Nsol225. }}$.

Simultaneous hybridization of biofilm samples with probes ALF1b and Ntspa662 designed for specific detection of the alpha-subclass of Proteobacteria and the genus Nitrospira, respectively, demonstrated that members of the genus Nitrospira are non-specifically targeted by probe ALF1b. Consistent with this finding, a recent data base inspection demonstrated that Nitrospira-like 16S rRNA-sequences retrieved from wastewater treatment plants possess the full match target site of probe ALF1b. Consequently, Nitrospiras have to be included in the list of non-alpha-subclass Proteobacteria targeted by probe ALF1b [8]. The relative biovolume labeled with probe ALF1b was higher than the one labeled with probe Ntspa662 in biofilm samples taken from reactor $R_{2}$, except for the last biofilm sample during phase III (Table 3). This demonstrates that an ALF1b-positive population not related to Nitrospira appeared in the biofilm when the hydraulic retention time changed from 0.8 to $5.0 \mathrm{~h}$, corresponding to the transition from reactor $\mathrm{R}_{0}$ to reactor $\mathrm{R}_{2}$ (phase II- $\mathrm{N}$ operation mode), and disappeared after the operation of reactor $\mathrm{R}_{2}$ with acetate for 50 days (phase III $-\mathrm{C}+\mathrm{N}$ operation mode).

The fraction of the alpha-Proteobacteria population (HET) developed in the biofilm from reactor $\mathrm{R}_{2}$ during pure nitrification (phase II) can be estimated as follows:

$\left(\text { Area }_{\mathrm{ALFlb}}\right)_{\mathrm{HET}}=$ Area $_{\mathrm{ALF} 1 \mathrm{~b}}-$ Area $_{\mathrm{Ntspa662}}$.

The fraction of biofilm and suspended biomass bacteria identified with specific gene probes $(\mathrm{F})$ in relation to all bacteria (EUB338 probe set) was calculated as listed below:

Biofilm samples

Area $_{\mathrm{ALF1b}} \approx$ Area $_{\mathrm{Ntspa662}} \Rightarrow \mathrm{F}=$ Area $_{\mathrm{BET} 42 \mathrm{a}}+$ Area $_{\mathrm{Ntspa662}}$,

Area $_{\mathrm{ALFlb}}>$ Area $_{\mathrm{Ntspa662}} \Rightarrow \mathrm{F}=$ Area $_{\mathrm{BET} 42 \mathrm{a}}+$ Area $_{\mathrm{ALFlb}}$.

Suspended biomass samples

$\mathrm{F}=$ Area $_{\mathrm{ALF} 1 \mathrm{~b}}+$ Area $_{\mathrm{BET} 42 \mathrm{a}}+$ Area $_{\mathrm{GAM} 42 \mathrm{a}}+$ Area $_{\mathrm{CF} 319 \mathrm{a}}$.

The population dynamics of nitrifiers and heterotrophs in the biofilm and suspended biomass from reactors $R_{0}, R_{1}$ and $R_{2}$ during the different phases of operation is depicted in Fig. 6. For most biofilm and suspension samples, more than $80 \%$ of the bacteria detectable by the EUB338 probe set could simulta- 
Table 3

Microbial community composition of reactors $\mathrm{R}_{0}, \mathrm{R}_{1}$ and $\mathrm{R}_{2}$ biofilm during the different phases of operation ${ }^{\mathrm{a}}$

\begin{tabular}{|c|c|c|c|c|c|c|c|c|}
\hline \multirow[t]{2}{*}{ Sample/reactor } & \multirow[t]{2}{*}{$\mathrm{NF}$} & \multicolumn{6}{|c|}{ Oligonucleotide probes } & \multirow[t]{2}{*}{$\mathrm{F}$} \\
\hline & & ALF1b & BET42a & Nso 1225 & NEU & Ntspa662 & NIT3 & \\
\hline \multicolumn{9}{|c|}{ Phase $\mathrm{I}-\mathrm{N}$ removal } \\
\hline $1 \mathrm{R}_{0}$ & 0.74 & - & $\begin{array}{l}39 \\
(53 \pm 4)\end{array}$ & $\begin{array}{l}39 \\
(53 \pm 4)\end{array}$ & $\begin{array}{l}\mathbf{2 5} \\
(34 \pm 3)\end{array}$ & $\begin{array}{l}\mathbf{3 8} \\
(52 \pm 4)\end{array}$ & $\begin{array}{l}\mathbf{0} \\
(0)\end{array}$ & 105 \\
\hline $2 \mathrm{R}_{0}$ & & - & - & - & $(56 \pm 5)$ & $(30 \pm 5)$ & 0 & - \\
\hline $3 \mathrm{R}_{0}$ & 0.74 & $\begin{array}{l}\mathbf{2 0} \\
(27 \pm 3)\end{array}$ & $\begin{array}{l}\mathbf{4 1} \\
(55 \pm 4)\end{array}$ & $\begin{array}{l}\mathbf{4 1} \\
(55 \pm 4)\end{array}$ & $\begin{array}{l}19 \\
(26 \pm 3)\end{array}$ & $\begin{array}{l}\mathbf{2 0} \\
(27 \pm 3)\end{array}$ & $\begin{array}{l}\mathbf{0} \\
(0)\end{array}$ & 82 \\
\hline \multicolumn{9}{|c|}{ Phase II $-\mathrm{N}$ removal } \\
\hline $4 \mathrm{R}_{1}$ & 0.68 & $\begin{array}{l}\mathbf{2 1} \\
(31 \pm 3)\end{array}$ & $\begin{array}{l}30 \\
(45 \pm 6)\end{array}$ & $\begin{array}{l}30 \\
(45 \pm 6)\end{array}$ & $\begin{array}{l}\mathbf{1 6} \\
(24 \pm 6)\end{array}$ & $\begin{array}{l}\mathbf{2 3} \\
(33 \pm 5)\end{array}$ & $\begin{array}{l}\mathbf{0} \\
(0)\end{array}$ & 78 \\
\hline $\mathrm{R}_{2}$ & 0.67 & $\begin{array}{l}35 \\
(52 \pm 3)\end{array}$ & $\begin{array}{l}21 \\
(31 \pm 5)\end{array}$ & $\begin{array}{l}21 \\
(31 \pm 5)\end{array}$ & $\begin{array}{l}\mathbf{1 4} \\
(21 \pm 3)\end{array}$ & $\begin{array}{l}27 \\
(41 \pm 2)\end{array}$ & $\begin{array}{l}\mathbf{0} \\
(0)\end{array}$ & 83 \\
\hline \multicolumn{9}{|c|}{ Phase III $-\mathrm{C}+\mathrm{N}$ removal } \\
\hline $5 \mathrm{R}_{1}$ & 0.68 & $\begin{array}{l}\mathbf{1 2} \\
(18 \pm 3)\end{array}$ & $\begin{array}{l}\mathbf{2 6} \\
(39 \pm 5)\end{array}$ & $\begin{array}{l}\mathbf{1 9} \\
(27 \pm 3)\end{array}$ & $\begin{array}{l}\mathbf{1 2} \\
(17 \pm 3)\end{array}$ & $\begin{array}{l}\mathbf{1 4} \\
(21 \pm 2)\end{array}$ & $\begin{array}{l}\mathbf{0} \\
(0)\end{array}$ & 59 \\
\hline $\mathrm{R}_{2}$ & 0.75 & $\begin{array}{l}30 \\
(40 \pm 7)\end{array}$ & $\begin{array}{l}29 \\
(39 \pm 5)\end{array}$ & $\begin{array}{l}\mathbf{2 1} \\
(28 \pm 7)\end{array}$ & $\begin{array}{l}19 \\
(25 \pm 5)\end{array}$ & $\begin{array}{l}\mathbf{2 3} \\
(30 \pm 6)\end{array}$ & $\begin{array}{l}\mathbf{0} \\
(0)\end{array}$ & 80 \\
\hline $6 \mathrm{R}_{1}$ & 0.70 & $\begin{array}{l}24 \\
(34 \pm 6)\end{array}$ & $\begin{array}{l}34 \\
(49 \pm 8)\end{array}$ & $\begin{array}{l}21 \\
(30 \pm 4)\end{array}$ & $\begin{array}{l}5 \\
(7 \pm 2)\end{array}$ & $\begin{array}{l}\mathbf{2 2} \\
(32 \pm 5)\end{array}$ & $\begin{array}{l}\mathbf{0} \\
(0)\end{array}$ & 81 \\
\hline $\mathrm{R}_{2}$ & 1.00 & $\begin{array}{l}29 \\
(29 \pm 6)\end{array}$ & $\begin{array}{l}\mathbf{6 0} \\
(60 \pm 4)\end{array}$ & $\begin{array}{l}\mathbf{0} \\
(0)\end{array}$ & $\begin{array}{l}\mathbf{0} \\
(0)\end{array}$ & $\begin{array}{l}31 \\
(31 \pm 6)\end{array}$ & $\begin{array}{l}3 \\
(3 \pm 1)\end{array}$ & 94 \\
\hline
\end{tabular}

${ }^{\mathrm{a}}$ The relative biovolumes of probe-defined bacterial populations (values in brackets) and the respective normalized values in regard to the biomass content of the samples (bold values) are given in columns 3-8. No normalized values are given for sample 2 since the biomass content was not determined for this sample. The fraction of bacteria detectable with the bacterial probe set, which were identified with specific oligonucleotide probes, is given in column 9 . Values listed in the table are the average percentage $\pm 95 \%$ confidence interval. For all biofilm samples no signals were observed with probes specific for the Cytophaga-Flavobacterium-cluster (CF319a) and the gamma-subclass of Proteobacteria (GAM42a), respectively. NF $=$ normalization factor; $-=$ not determined.

Table 4

Microbial community composition of reactors $\mathrm{R}_{1}$ and $\mathrm{R}_{2}$ suspended biomass during combined nitrification and organic carbon removal (columns 3-6) ${ }^{\mathrm{a}}$

\begin{tabular}{|c|c|c|c|c|c|c|}
\hline \multirow[t]{2}{*}{ Sample/reactor } & \multirow[t]{2}{*}{ NF } & \multicolumn{4}{|c|}{ Oligonucleotide probes } & \multirow[t]{2}{*}{$\mathrm{F}$} \\
\hline & & ALF1b & BET42a & GAM42a & CF319a & \\
\hline \multicolumn{7}{|c|}{ Phase III $-\mathrm{C}+\mathrm{N}$ removal } \\
\hline $5 \mathrm{R}_{1}$ & 0.18 & $\begin{array}{l}\mathbf{2 . 2} \\
(12 \pm 1)\end{array}$ & $\begin{array}{l}\mathbf{1 1 . 5} \\
(64 \pm 2)\end{array}$ & $\begin{array}{l}\mathbf{0} \\
(0)\end{array}$ & $\begin{array}{l}\mathbf{0 . 2} \\
(1 \pm 0)\end{array}$ & 76 \\
\hline $\mathrm{R}_{2}$ & 0.17 & $\begin{array}{l}\mathbf{1 . 6} \\
(10 \pm 1)\end{array}$ & $\begin{array}{l}\mathbf{1 4} \\
(81 \pm 1)\end{array}$ & $\begin{array}{l}\mathbf{0 . 5} \\
(3 \pm 0)\end{array}$ & $\begin{array}{l}\mathbf{0 . 9} \\
(5 \pm 1)\end{array}$ & 99 \\
\hline $6 \mathrm{R}_{1}$ & 0.18 & $\begin{array}{l}3.1 \\
(17 \pm 3)\end{array}$ & $\begin{array}{l}\mathbf{1 4 . 6} \\
(81 \pm 2)\end{array}$ & $\begin{array}{l}\mathbf{0 . 2} \\
(1 \pm 0)\end{array}$ & $\begin{array}{l}\mathbf{0 . 2} \\
(1 \pm 0)\end{array}$ & 100 \\
\hline $\mathrm{R}_{2}$ & 0.17 & $\begin{array}{l}\mathbf{1 . 2} \\
(7 \pm 1)\end{array}$ & $\begin{array}{l}13 \\
(77 \pm 4)\end{array}$ & $\begin{array}{l}\mathbf{1 . 9} \\
(11 \pm 1)\end{array}$ & $\begin{array}{l}\mathbf{1 . 5} \\
(9 \pm 2)\end{array}$ & 104 \\
\hline
\end{tabular}

\footnotetext{
${ }^{a}$ Column 7 displays the fraction of bacteria detectable with the bacterial probe set which were identified with specific oligonucleotide probes. Values listed in the table are the average percentage $\pm 95 \%$ confidence interval (values in brackets). NF $=$ normalization factor.
}

neously be classified by at least one of the more specific probes applied (Tables 3 and 4; Eqs. 3-5). However, this does not hold true for the biofilm and suspended biomass samples taken from reactor $R_{1}$ during the accidental overloading period with ammonium (sample 5). In this sample $41 \%$ of the biofilm bacteria and $24 \%$ 


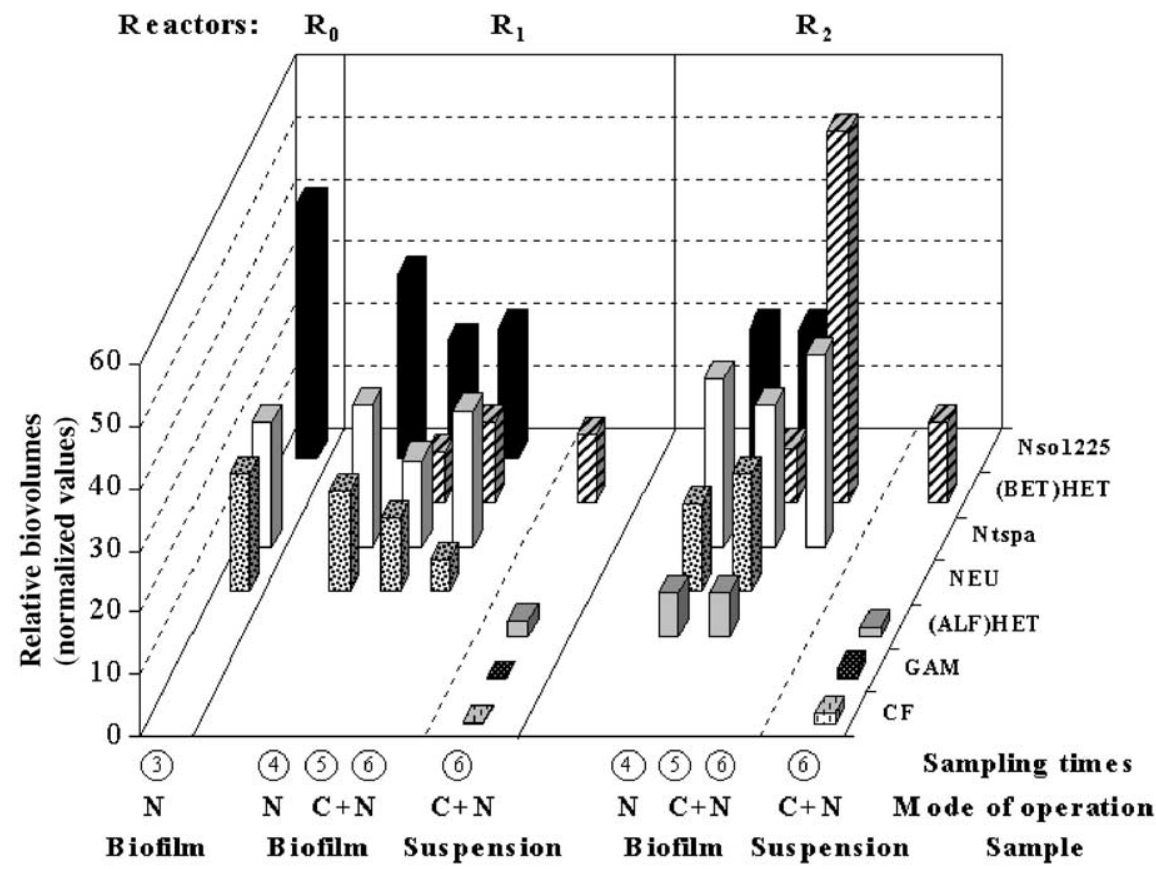

Fig. 6. Population dynamics of ammonia-oxidizers, nitrite-oxidizers and heterotrophs in the biofilm during process operation of reactors $R_{1}$ and $R_{2}$ with pure nitrification [phase I (sampling point 3) and phase II (sampling point 4)] and combined nitrification and organic carbon removal (phase III - sampling points 5 and 6). In addition, the microbial community composition of the suspended biomass is displayed for both reactors for sampling point 6 .

of the suspended bacteria which were detectable by FISH could not further be classified with the more specific probes. Whether these bacteria appeared in the reactor due to the acetate addition or the elevated ammonia concentrations could not be clarified.

\subsection{Population dynamics during phase I}

Biofilm samples were taken before and after the storage period preceding operation of reactor $\mathrm{R}_{0}$ (samples 1 and 2) and after 112 days of operation (sample 3), in order to evaluate the effects of the storage period on the microbial community composition.

The samples were hybridized in situ with probes Nso1225, NEU and Ntspa662, as well as the EUB338 probe set. After the storage period (sample 2) the fraction of ammonia-oxidizers was larger than during normal operation (samples 1 and 3) while the relative abundance of nitrite-oxidizers decreased (data not shown), suggesting that the nitrite-oxidizers decayed faster than the ammonia-oxidizers under the selected storage conditions. The characterization of the biofilm from reactor $\mathrm{R}_{0}$ during operation (sample 3 ) showed that the ammonia-oxidizing population detected with probe Nso1225 was able to recover a comparable relative abundance as before the storage period (sample 1), while the nitrite-oxidizing population decreased considerably from $38 \%$ (sample 1 ) to $20 \%$ (sample 3 ). Furthermore, the morphology of the nitrite-oxidizing clusters changed from big clusters present before the storage period (sample 1), to small ones mixed with netlike structures afterwards (sample 3). Despite the decrease in the relative abundance of nitrite-oxidizers, no nitrite accumulation was observed during phase I. This suggests that the nitrite-oxidizers present in net-like structures in sample 3 are more active (possibly due to a better accessibility to substrates) than those occurring in big clusters in sample 1 .

\subsection{Population dynamics during phase II}

In the transition from phases I to II the amount of biofilm particles from reactor $\mathrm{R}_{0}$ was split up between reactors $\mathrm{R}_{1}$ and $\mathrm{R}_{2}$, while the $\mathrm{NH}_{4}^{+}-\mathrm{N}$ load per reactor was reduced from 1.24 to $0.48-0.61 \mathrm{~kg} \mathrm{~m}^{-3} \mathrm{~d}^{-1}$. Despite the lower amount of biofilm particles in $R_{1}$ and $R_{2}$ than in $\mathrm{R}_{0}$, the biomass concentration per reactor volume was similar in both reactors during phases I and II (Table 2). This can be explained by a lower biofilm detachment rate in reactors $R_{1}$ and $R_{2}$ caused by a decrease in the 
collision frequency between biofilm particles. Consequently, the $\mathrm{NH}_{4}^{+}-\mathrm{N}$ load to biomass ratio was higher in $\mathrm{R}_{0}\left(0.46 \mathrm{~kg} \mathrm{~kg}^{-1} \mathrm{~d}^{-1}\right)$ than in $\mathrm{R}_{1}\left(0.25 \mathrm{~kg} \mathrm{~kg}^{-1} \mathrm{~d}^{-1}\right)$ and $\mathrm{R}_{2}\left(0.24 \mathrm{~kg} \mathrm{~kg}^{-1} \mathrm{~d}^{-1}\right)$. As a result the effluent $\mathrm{NH}_{4}^{+}-\mathrm{N}$ concentration of the reactors dropped from $1.8 \mathrm{mgl}^{-1}$ $\left(\mathrm{R}_{0}\right)$ to $0.6 \mathrm{mgl}^{-1}\left(\mathrm{R}_{1}\right)$ and $0.2 \mathrm{mgl}^{-1}\left(\mathrm{R}_{2}\right)$, respectively. The normalized abundance of ammonia-oxidizers in the biofilm decreased from reactor $\mathrm{R}_{0}$ (sample 3 ) to reactor $\mathrm{R}_{1}$ (sample 4) and reactor $\mathrm{R}_{2}$ (sample 4), respectively (Fig. 6; Table 3). The $\mathrm{NH}_{4}^{+}-\mathrm{N}$ concentration in reactors $\mathrm{R}_{1}$ and $\mathrm{R}_{2}$ was lower than the assumed saturation constant of $0.7 \mathrm{mg}^{-1}$ [18], and thus most likely limited the amount of ammonia-oxidizers in the biofilm. Unlike the ammonia-oxidizing population the relative abundance of nitrite-oxidizers increased in $\mathrm{R}_{2}$ and remained approximately constant in $\mathrm{R}_{1}$ during phase II (N operation). According to Eq. (2), in reactor $R_{2}$ a heterotrophic population $(8 \%)$ detectable with probe ALF1b developed.

\subsection{Population dynamics during phase III}

The newly introduced supply of acetate during phase III induced the growth of heterotrophic microorganisms both in suspension and in the biofilm in both reactors. Biofilm samples collected 12 days after acetate addition (sample 5) showed the presence of a thin layer of heterotrophic beta-Proteobacteria distributed discontinuously on top of the nitrifying biofilm, accounting for $7-8 \%$ of the bacterial biofilm population in both reactors. Like during phase II, a heterotrophic population detectable with probe ALF1b (7\%) was exclusively present in reactor $\mathrm{R}_{2}, 12$ days after addition of acetate. During the first 12 days of phase III the abundance of nitrite-oxidizers decreased in the biofilm of both reactors, while the ammonia-oxidizers decreased only in $R_{1}$. The latter observation corresponds with the higher loss of ammonium removal observed in reactor $\mathrm{R}_{1}$, (28\% loss) compared to reactor $\mathrm{R}_{2}$ (19\% loss).

The ammonium removal in reactor $R_{2}$ continued to decrease during the subsequent days of acetate addition until a complete breakdown of the nitrification process happened. After 50 days of acetate addition (sample 6), no ammonia-oxidizing bacteria could be detected in reactor $R_{2}$ while the relative in situ abundance of Nitrospira-like nitrite-oxidizers was similar to the one during phase II ( $\mathrm{N}$ operation). At that time reactor $\mathrm{R}_{2}$ biofilm was dominated by heterotrophic beta-Proteobacteria that amounted to $60 \%$ of the total biovolume labeled with the bacterial probe set. In contrast to reactor $R_{2}$, the extended addition of acetate did not cause a complete breakdown of nitrification in reactor $\mathrm{R}_{1}$. In this reactor, the ammonium removal efficiency stabilized at $69 \%$ and the heterotrophic beta population in the biofilm amounted to a maximum biovolume fraction of only $13 \%$ (sample 6 ). As in reactor $R_{2}$, the nitrite-oxidizing population in reactor $R_{1}$ did recover its initial relative abundance during prolonged acetate dosage.

\section{Discussion}

In this study the microbial community composition and dynamics in two nitrifying biofilm reactors (differing in hydraulic retention time) was monitored using molecular tools during a shift in process operation from pure nitrification to combined nitrification and organic carbon removal. In general, the dynamics of the microbial communities correlated well with the performance of the respective reactors. In the following sections several interesting findings are discussed in more detail.

\subsection{Composition and dynamics of bacterial populations in the reactors}

In both reactors at least two populations of betasubclass ammonia-oxidizers were present. As demonstrated by oligonucleotide probing and comparative AmoA sequence analysis, one of these populations was closely related to the model organism Nitrosomonas europaea, while the other population surprisingly showed no close relationship with recognized ammonia-oxidizers. Nitrite oxidation was catalyzed in both reactors mainly by Nitrospira-like bacteria confirming the recently recognized importance of these bacteria for nitrite oxidation in several environments (e.g. $[13,14,19])$. In both reactors Nitrospiras occurred in previously not observed net-like structures in the biofilm. In the present work, Nitrobacter could only be detected in small numbers in the biofilm of reactor $R_{2}$ during simultaneous addition of acetate and ammonium (phase III) and a concurrent increase of the $\mathrm{NO}_{2}^{-}-\mathrm{N}$ concentration from $0.02 \mathrm{mgl}^{-1}$ (phase II) to $0.39 \mathrm{mgl}^{-1}$ (phase III). This result is consistent with the recently published hypothesis that Nitrospiras are k-strategists (and thus thrive at low nitrite concentrations) while Nitrobacter as r-strategist can compete successfully only in environments with relatively high nitrite concentrations [19]. The absence of detectable Nitrobacters in reactor $\mathrm{R}_{1}$ during phase III might have been caused by the lower $\mathrm{NO}_{2}^{-}-\mathrm{N}$ accumulation $\left(0.22 \mathrm{mgl}^{-1}\right)$ in this reactor compared to reactor $\mathrm{R}_{2}$. In addition, Nitrobacter might have benefited in phase III in $R_{2}$ from its capability to grow mixotrophically with acetate while Nitrospiras might not possess this capability [14]. On the other hand we yet have no explanation for the observed increase of Nitrospira-like nitrite oxidizers during phase III in both reactors despite the decreasing or even failing nitrification during this period. 
Despite the lack of organic carbon dosing during phase II a presumably heterotrophic population affiliated with the alpha-subclass Proteobacteria was present in the biofilm of reactor $\mathrm{R}_{2}(5.0 \mathrm{~h}$ retention time), but disappeared during reactor operation with acetate (end of phase III). Most likely this population was growing on soluble microbial products (SMP) formed by active nitrifiers in the biofilm [20] since SMP concentration should be higher in reactor $R_{2}$ than in reactor $R_{1}$ due to the difference in retention time. In phase III the supply of acetate provoked the breakdown of the nitrification process in reactor $\mathrm{R}_{2}$, consequently SMP were no longer produced and the alpha-proteobacterial population disappeared from the biofilm.

During combined nitrification and organic carbon removal in phase III a higher group-level diversity of heterotrophic microorganisms was found in suspension than in the biofilm. This result might be explained by the fact that the heterotrophic biofilm community is exposed to a higher shear stress compared to the suspended consortia. Thus, only fast growing heterotrophs can maintain themselves in the outer layer of the biofilm, a selection pressure which might reduce diversity.

\subsection{Population dynamics versus reactor performance}

During phase II (pure nitrification) the biofilm was, as expected, dominated by ammonia- and nitrite-oxidizing bacteria in both reactors. After acetate addition (phase III), the formation of a thicker layer of heterotrophic bacteria in reactor $R_{2}$ (with long retention time) on the surface of the nitrifying biofilm led to increased oxygen mass transfer resistance from bulk liquid to the nitrifiers. This coincided with a drastic reduction in the ammoniaoxidizing population and a subsequent breakdown of the nitrification process. In contrast, reactor $\mathrm{R}_{1}$ operated with short retention time displayed a smaller increase of heterotrophic biofilm bacteria on the surface which corresponded to the less pronounced reduction in nitrification performance. An alternative hypotheses for the breakdown of the nitrification in reactor $R_{2}$ during phase III would be that nitrifiers but not the heterotrophs were lost from the biofilm due to detachment and finally washed out of the reactor. This would be consistent with the absence of in situ detectable ammonia-oxidizers in sample 6 of reactor $R_{2}$. However, there are two lines of evidence that oxygen limitation and not selective washout caused the nitrification breakdown. Firstly, the even slower growing nitriteoxidizers still were detected in significant amounts (31\%) within the biofilm of reactor $\mathrm{R}_{2}$ at the end of phase III. Secondly, the re-establishment of $90 \%$ of the nitrification capacity within 14 days after stop of acetate addition (Fig. 4; phase IV) in reactor $\mathrm{R}_{2}$ contradicts the possibility of a previous complete depletion of ammonia-oxidizers. The mass accumulation rate for nitrifying biofilm of $0.03 \mathrm{~kg} \mathrm{~m}^{-3} \mathrm{~d}^{-1}$, [21] excludes the chance of such a fast recovery by re-growth. Keeping in mind previously published data [2] our findings were unexpected since we assumed that reactor $\mathrm{R}_{2}$ will, due to its longer retention time, favor suspended growth of the fast reproducing heterotrophs and thus allow for a higher biofilm-mediated nitrification during the presence of acetate.

What remains to be discussed is (i) why a thicker heterotrophic biofilm is formed on top of the nitrifying biofilm in reactor $R_{2}$ compared to reactor $R_{1}$ and (ii) why heterotrophic biofilm formation and subsequent loss of nitrifying capacity was not observed in the airlift reactor of [2] after addition of organic carbon. Heterotrophic biofilm formation in reactor $R_{2}$ could be explained by increased liquid phase viscosity in this reactor due to the presence of extracellular biopolymers which accumulated compared to reactor $R_{1}$ due to the increased liquid retention time in reactor $R_{2}$. Increased liquid viscosity will lead to a stronger air bubble coalescence, thus decreasing the volume occupied by the gas phase, reducing the driving force for the circulation and ultimately the shear stress for the biofilm ([22,23]). Consistent with this argumentation, surface protuberances were observed by us microscopically in the biofilm of $\mathrm{R}_{2}$ (reflecting the lower shear stress) while the biofilm of reactor $R_{1}$ was characterized by a much smoother biofilm surface (indicative for a higher shear stress [23]). Differences in liquid phase viscosity or other factors influencing turbulence and thus shear stress and substrate availability (e.g. reactor geometry, friction, structure of the biofilm support particles etc.) could also be responsible for the inconsistent results between this study and the work of van Benthum and co-workers. Independent from the actual reason(s) causing these inconsistent results of both studies, it is important to note that extension of hydraulic retention time caused dramatically different effects in similar biofilm reactors.

\section{Conclusions}

The following main conclusions can be drawn from the present study:

1. No major effect of the hydraulic retention time on the diversity of nitrifying bacteria in the biofilm was observed. A group of ammonia-oxidizers not closely related to any described reference strain was identified in the biofilm from both reactors showing that even in systems working with defined conditions, the bacterial diversity is not completely described.

2. Combined nitrification and carbon removal under oxygen limiting conditions could be accomplished in the biofilm reactor with low hydraulic retention time but failed in the reactor with high hydraulic retention 
time. This unexpected finding was caused by the formation of a thick heterotrophic layer on top of the nitrifying biofilm in the latter reactor that limited the nitrifiers' oxygen supply. Thus, extension of the hydraulic retention time is not always sufficient to improve combined nitrification and organic carbon removal in biofilm reactors.

3. Today, the battery of molecular tools allows to precisely determine ecological key parameters of complex microbial communities present in engineered systems. In addition to species richness and evenness also the in situ activity of probe identified bacteria can be analyzed [24]. Future interdisciplinary research at the interface between molecular microbial ecology and civil engineering will almost certainly allow for a detailed understanding of the links between microbial diversity, process efficiency and process stability. For example, it should be possible by the use of molecular methods to define operational parameters which selectively increase the diversity within important functional groups of bacteria (e.g. nitrifiers) and thus render the microbial community more resistant against perturbations. Armed with such knowledge innovative strategies for process control and design as well as for bioaugmentation can be developed.

\section{Acknowledgements}

This work was supported by the Portuguese Ministry of Science and Technology (PRAXIS XXI BD/15943/ 98), the Deutscher Akademischer Austauschdienst (A/ 99/06961) and the European Comission (T.M.R. program, BioToBio project). Ulrike Purkhold was supported by Sonderforschungsbereich 411 from the Deutsche Forschungsgemeinschaft (Research Center for Fundamental Studies of Aerobic Biological Wastewater Treatment; project A2).

\section{References}

[1] Tijhuis L, Rekswinkel HG, van Loosdrecht MCM, Heijnen JJ. Dynamics of population and biofilm structure in the biofilm airlift suspension reactor for carbon and nitrogen removal. Water Sci Technol 1994;29:377-84.

[2] van Benthum WAJ, van Loosdrecht MCM, Heijnen JJ. Control of heterotrophic layer formation on nitrifying biofilms in a biofilm airlift suspension reactor. Biotechnol Bioeng 1997;53(4):397-405.

[3] Ohashi A, de Silva DGV, Mobarry B, Manem J, Stahl D, Rittmann BE. Influence of the substrate $\mathrm{C} / \mathrm{N}$ ratio on the structure of multi-species biofilms consisting of nitrifiers and heterotrophs. Water Sci Technol 1995;32(8):75-84.
[4] Furumai H, Rittmann BE. Evaluation of multiple-species biofilm and floc processes using a simplified aggregate model. Water Sci Technol 1994;29(10-11):439-46.

[5] Lazarova V, Manem J. An innovative process for waste water treatment: the circulating bed reactor. Water Sci Technol 1996;34(9):89-99.

[6] APHA. Standard methods for the examination of water and wastewater. 19th ed. New York: American Public Health Association, 1995.

[7] Daims H, Brühl A, Amann R, Schleifer K-H, Wagner M. The domain - specific probe EUB338 is insufficient for the detection of all Bacteria: development and evaluation of a more comprehensive probe set. Syst Appl Microbiol 1999;22:434- 44.

[8] Manz W, Amann R, Ludwig W, Wagner M, Schleifer KH. Phylogenetic oligonucleotide probes for the major subclasses of Proteobacteria: problems and solutions. Syst Appl Microbiol 1992;15:593-600.

[9] Manz W, Amann R, Ludwig W, Vancanneyt M, Schleifer K-H. Application of a suite of 16S rRNAspecific oligonucleotide probes designed to investigate bacteria of the phylum Cytophaga-FlavobacterBacteroides in the natural environment. Microbiol 1996;142:1097-106.

[10] Wagner M, Rath G, Amann R, Koops H-P, Schleifer K$\mathrm{H}$. In situ identification of ammonia-oxidizing bacteria. Syst Appl Microbiol 1995;18:251-64.

[11] Wagner, M, Rath G, Koops H-P, Flood J, Amann R. In situ analysis of nitrifying bacteria in sewage treatment plants. Water Sci Technol 1996;34(1):237-44.

[12] Mobarry BK, Wagner M, Urbain V, Rittmann BE, Stahl DA. Phylogenetic probes for analysing abundance and spatial organization of nitrifying bacteria. Appl Environ Microbiol 1996;62(6):2156-62.

[13] Juretschko S, Timmermann G, Schmid M, Schleifer K-H, Pommerening-Röser A, Koops H-P, Wagner M. Combined molecular and concentional analyses of nitrifying bacterium in activated sludge: Nitrosococcus mobilis and Nitrospira-like bacteria as dominant populations. Appl Environ Microbiol 1998;64(8):3042-51.

[14] Daims H, Nielsen P, Nielsen JL, Juretschko S, Wagner M. Novel Nitrospira-like bacteria as dominant nitrite-oxidizers in biofilms from wastewater treatment plants: diversity and in situ physiology. Water Sci Technol 2000;41(4 5):85-90.

[15] Schmid M, Twachtmann U, Klein M, Strous M, Juretschko S, Jetten M, Metzger J, Schleifer K-H, Wagner M. Molecular evidence of genus level diversity of bacteria capable of catalysing anaerobic ammonium oxidation. Syst Appl Microbiol 2000;23:93-106.

[16] Purkhold U, Pommerening-Röser A, Juretschko S, Schmid MC, Koops H-P, Wagner M. Phylogeny of all recognized species of ammonia-oxidizers based on comparative $16 \mathrm{~S}$ rRNA and amoA sequence analyses: implications for molecular diversity surveys. Appl Environ Microbiol 2000;66(12):5368-82.

[17] Wagner M, Noguera DR, Juretschko S, Rath G, Koops H-P, Amann R. Combining fluorescent in situ hybridization (FISH) with cultivation and mathematical modeling to study population structure and function of ammonia- 
oxidizing bacteria in activated. Water Sci Technol 1998;37(4-5):441-9.

[18] Wiesmann U. Biological nitrogen removal from wastewater. In: Fietcher A, editor. Advances in biochemical engineering biotechnology, vol. 51. Berlin Heidelberg Germany: Springer, 1994. p. 113-54.

[19] Schramm A, de Beer D, van den Heuvel JC, Ottengraf S, Amann R. Microscale distribution of populations and activities of Nitrosospira and Nitrospira spp. along a macroscale gradient in a nitrifying bioreactor: quantification by in situ hybridization and the use of microsensors. Appl Environ Microbiol 1999;65(8):3690-6.

[20] Rittmann BE, Regan JM, Stahl DA. Nitrification as a source of soluble organic substrate in biological treatment. Water Sci Technol 1994;30(6):1-8.

[21] Garrido-Fernández J, Méndez R, Lema JM, Lazarova V. The circulating floating ber reactor: effect of particle size distribution of the carrier on ammonia convertion. Conference on Biofilm Systems. New York, 1999, 17-20 October.

[22] Akita K, Yoshida F. Gas holdup and volumetric mass transfer coefficient in bubble columns. Ind Eng Chem, Process Des Dev 1993;12:76-80.

[23] Kwok WK, Picioreanu C, Ong SL, van Loosdrecht MCM, Heijnen JJ. Influence of biomass production and detachment forces on biofilm structures in a biofilm suspension airlift reactor. Biotechnol Bioeng 1998;58(4):400-7.

[24] Lee N, Nielsen PH, Andreasen KH, Juretschko S, Nielsen JL, Schleifer K-H, Wagner M. Combination of fluorescent in situ hybridization and microautoradiography - a new tool for the structure-function analyses in microbial ecology. Appl Environ Microbiol 1999; 65(3):1289-97. 